\title{
A New Pineapple Cultivar, Tainung No. 23, with Improved Fruit Quality in Summer
}

\section{Chia-Hui Tang and Ching-Shan Kuan}

Chiayi Agricultural Experiment Branch, Taiwan Agricultural Research Institute (TARI), Horticulture Division, 2 Min-Cheng Road, Chiayi City, Taiwan, Republic of China

\section{Su-Feng Roan}

Department of Horticulture and Biotechnology, Chinese Culture University, Taipei, Taiwan, Republic of China

\section{Chin-Lung Lee}

Department of Landscape Architecture and Horticulture, National Taiwan University, Taipei, Republic of China

\section{Jer-Way Chang}

Chiayi Agricultural Experiment Station, Taiwan Agricultural Research Institute (TARI), Horticulture Division, 2 Min-Cheng Road, Chiayi City, Taiwan, Republic of China

\section{Iou-Zen Chen}

Department of Landscape Architecture and Horticulture, National Taiwan University, Taipei, Republic of China

Additional index words. noncracking peel, hybrid pineapple, mechanized farming, fruit storage

The fruit quality of most pineapple cultivars in Taiwan is not satisfactory during hot summers. Herein, we describe the results of selective breeding in a TARI pineapple breeding orchard. A regional trials program was launched in 2008 for evaluation of superior pineapple lines and varieties, with a focus on developing a shorter plant and improving fruit quality in summer. In 2018, a new cultivar was obtained, released as Tainung No. 23; it was selected from a hybridization population and successive field trials. This cultivar demonstrated improved fruit quality in summer and a shorter plant, with increased suitability for mechanized management.
Pineapple [Ananas comosus (L.) Merr.] is one of Taiwan's major commercial fruits, with 10,490 ha under cultivation, yielding $\approx 432,083$ tons valued at nearly $\$ 306$ million U.S. dollars (9 billion New Taiwan dollars) (Agriculture Statistics Yearbook, COA of Republic of China, 2018). Currently, the main pineapple cultivar in Taiwan is Tainung No. 17 (TNG.17), also known as Gold Diamond. It is popular and well accepted because of its large fruits, high total soluble solid (TSS) content $\left(14.5{ }^{\circ}\right.$ Brix), low titratable acidity (TA) $(0.28 \%)$, tender flesh, and suitable harvest time in spring (Chang et al., 1999). However, in the hot and humid season, Tainung No. 17 fruit is of reduced quality (Tsai et al., 2015) and shows stem-end splitting, cracking peels, higher cut wound surface discoloration, and other problems during fruit development (Wu, 2012). Thus, there is a need for cultivars to produce fruits in summer with higher TSS and higher TA than those of Tainung No. 17, as well as fewer incidences of splitting, cracking, and peduncle wound surface discoloration. We carried out a pineapple cultivar breeding project from 1991 to 2013 to select a new cultivar with a more suitable fruit. After a series of hybridizations by hand pollination, 17,653 and 23,343 seeds were harvested in 1991 and 1993, which were grown in sphagnum moss in a plastic net house in 1992 and 1994, respectively. Three-year-old seedlings were transplanted to the orchard for two progeny tests.

\section{Description}

Three selection trials were performed in this breeding program, as described next.

Progeny test and superior line selection. Two progeny tests were conducted. The selection population for the first test was from seedlings produced in 1991 and

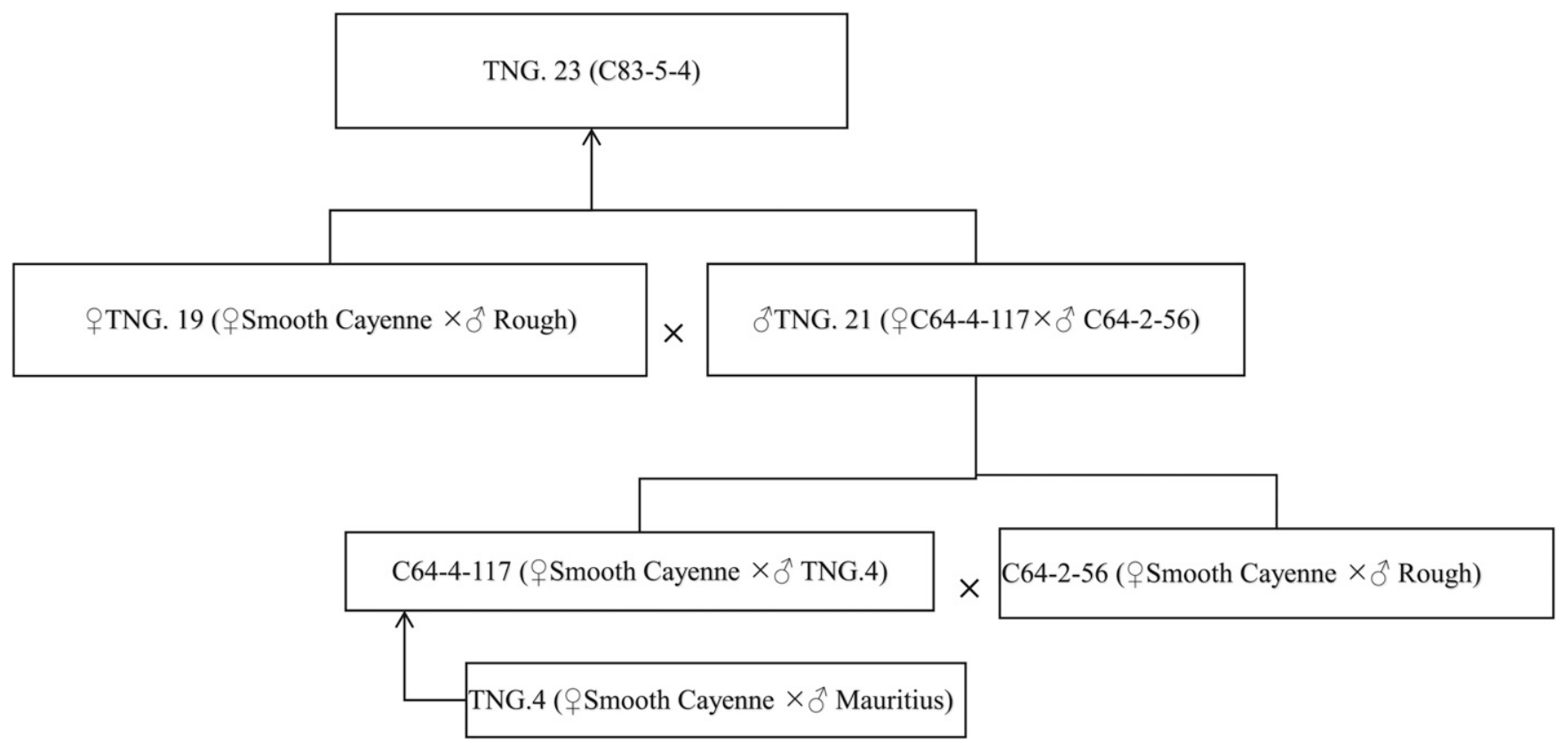

Fig. 1. Genealogy of TNG.23 (C83-5-4). 
Table 1. Characteristics of selected pineapple hybrids in the second progeny test.

\begin{tabular}{|c|c|c|c|c|c|c|c|c|c|}
\hline \multirow[b]{2}{*}{ Line } & \multirow[b]{2}{*}{ Plant ht $(\mathrm{cm})$} & \multicolumn{3}{|c|}{ Leaf } & \multicolumn{4}{|c|}{ Fruit } & \multirow{2}{*}{$\begin{array}{c}\text { Pass }(\mathrm{P}) \text { or } \\
\text { Elimination }(\mathrm{E})^{\mathrm{z}}\end{array}$} \\
\hline & & Length $(\mathrm{cm})$ & Width $(\mathrm{cm})$ & No. & Wt (g) & Length $(\mathrm{cm})$ & Width $(\mathrm{cm})$ & Fruitlet (no.) & \\
\hline$\overline{\mathrm{C} 81-1-8}$ & $84.2 b^{y}$ & $76.4 \mathrm{c}$ & $6.0 \mathrm{ab}$ & $44 \mathrm{a}$ & $1,120 \mathrm{c}$ & $15.4 \mathrm{bc}$ & $11.4 \mathrm{c}$ & $91.7 \mathrm{~d}$ & $\mathrm{E}$ \\
\hline C81-1-17 & $96.8 \mathrm{a}$ & 85.9 a & $5.7 \mathrm{ab}$ & $38 \mathrm{bc}$ & $1,548 \mathrm{bc}$ & $17.2 \mathrm{~b}$ & $12.1 \mathrm{bc}$ & $168.3 \mathrm{bc}$ & $\mathrm{P}$ \\
\hline C81-2-3 & $98.0 \mathrm{a}$ & $86.4 \mathrm{a}$ & $6.1 \mathrm{a}$ & $37 \mathrm{c}$ & $1,578 \mathrm{bc}$ & $14.6 \mathrm{c}$ & $12.7 \mathrm{~b}$ & $137.2 \mathrm{~cd}$ & $\mathrm{P}$ \\
\hline C81-3-216 & $89.9 \mathrm{~b}$ & $83.9 \mathrm{ab}$ & $5.6 \mathrm{~b}$ & $42 \mathrm{ab}$ & $1,865 \mathrm{~b}$ & $18.0 \mathrm{ab}$ & $12.8 \mathrm{~b}$ & $228.1 \mathrm{a}$ & $\mathrm{P}$ \\
\hline C81-3-264 & $88.6 \mathrm{~b}$ & $80.6 \mathrm{~b}$ & $5.0 \mathrm{c}$ & $32 \mathrm{~d}$ & $2,800 \mathrm{a}$ & $20.2 \mathrm{a}$ & $14.4 \mathrm{a}$ & $202.7 \mathrm{ab}$ & $\mathrm{E}$ \\
\hline$\overline{C 83-1-26}$ & $96.5 \mathrm{ab}$ & $79.8 \mathrm{~b}$ & $5.0 \mathrm{~b}$ & $53 \mathrm{a}$ & $1,620 \mathrm{ab}$ & $17.7 \mathrm{ab}$ & $12.0 \mathrm{ab}$ & $144 \mathrm{~b}$ & $\mathrm{E}$ \\
\hline C83-1-387 & $118.3 \mathrm{a}$ & $108.0 \mathrm{a}$ & $7.0 \mathrm{a}$ & $32 \mathrm{~b}$ & $1,960 \mathrm{ab}$ & $18.5 \mathrm{ab}$ & $12.2 \mathrm{ab}$ & $260 \mathrm{a}$ & $\mathrm{E}$ \\
\hline C83-1-432 & $104.2 \mathrm{ab}$ & $91.2 \mathrm{~b}$ & $6.0 \mathrm{ab}$ & $39 \mathrm{ab}$ & $1,160 \mathrm{~b}$ & $15.2 \mathrm{~b}$ & $10.8 \mathrm{~b}$ & $126 \mathrm{~b}$ & $\mathrm{P}$ \\
\hline C83-1-534 & $86.8 \mathrm{ab}$ & $79.0 \mathrm{~b}$ & $7.5 \mathrm{a}$ & $41 \mathrm{ab}$ & $1,372 \mathrm{~b}$ & $17.0 \mathrm{ab}$ & $10.6 \mathrm{~b}$ & $236 \mathrm{a}$ & $\mathrm{E}$ \\
\hline C83-2-184 & $79.0 \mathrm{~b}$ & $79.0 \mathrm{~b}$ & $5.0 \mathrm{~b}$ & $35 \mathrm{ab}$ & $2,060 \mathrm{a}$ & $20.0 \mathrm{a}$ & $14.0 \mathrm{a}$ & $247 \mathrm{a}$ & $\mathrm{E}$ \\
\hline C83-2-750 & $93.0 \mathrm{ab}$ & $93.0 \mathrm{ab}$ & $6.0 \mathrm{ab}$ & $34 \mathrm{ab}$ & $1,620 \mathrm{ab}$ & $18.0 \mathrm{ab}$ & $12.0 \mathrm{ab}$ & $260 \mathrm{a}$ & $\mathrm{E}$ \\
\hline C83-5-4 & $86.2 \mathrm{ab}$ & $67.2 \mathrm{c}$ & $6.2 \mathrm{ab}$ & $41 \mathrm{ab}$ & $1,520 \mathrm{ab}$ & $17.1 \mathrm{ab}$ & $12.7 \mathrm{ab}$ & $130 \mathrm{~b}$ & $\mathrm{P}$ \\
\hline
\end{tabular}

${ }^{\mathrm{z}}$ Criteria used to determine a pass: fruits with excellent appearance and firmness, ease of harvest, and good eating quality, as determined by five associates from a trained panel of the Chiayi Agricultural Experiment Station.

${ }^{\mathrm{y}}$ Means followed by different letters in a column, within the same year, represent significant differences at the 5\% level by Fisher's protected least significant difference test.

Table 2. Comparison of horticultural characteristics among Smooth Cayenne, TNG. 17, and five selected superior lines of pineapple in summer.

\begin{tabular}{|c|c|c|c|c|c|c|c|c|}
\hline \multirow[b]{2}{*}{ Cultivar/selection } & \multirow[b]{2}{*}{ Wt per fruit (g) } & \multicolumn{2}{|c|}{40,000 plants per hectare } & \multirow[b]{2}{*}{$\mathrm{TSS}^{\mathrm{y}}\left({ }^{\circ} \mathrm{Brix}\right)$} & \multirow[b]{2}{*}{$\mathrm{TA}^{\mathrm{y}}(\%)$} & \multirow[b]{2}{*}{ TSS/TA ratio } & \multirow[b]{2}{*}{ Pulp ${ }^{x}$ fiber } & \multirow[b]{2}{*}{ Pulp $^{\mathrm{x}}$ texture } \\
\hline & & Yield (t/ha) & $\operatorname{Index}^{\mathrm{z}}(\%)$ & & & & & \\
\hline$\overline{C 81-1-17}$ & $1,699 \mathrm{ab}^{\mathrm{w}}$ & 67.9 & 145 & $14.9 \mathrm{e}$ & $0.42 \mathrm{ab}$ & $36 \mathrm{c}$ & Rough & $++^{v}$ \\
\hline C81-2-3 & $1,543 \mathrm{~b}$ & 61.7 & 132 & $15.1 \mathrm{e}$ & $0.33 \mathrm{c}$ & $46 \mathrm{a}$ & Smooth & ++ \\
\hline C81-3-216 & $1,520 \mathrm{bc}$ & 60.7 & 129 & $15.8 \mathrm{~cd}$ & $0.37 \mathrm{bc}$ & $45 \mathrm{a}$ & Smooth & +++ \\
\hline C83-1-432 & $1,585 \mathrm{~b}$ & 63.4 & 135 & $19.6 \mathrm{a}$ & $0.46 \mathrm{a}$ & $43 \mathrm{ab}$ & Medium & ++ \\
\hline C83-5-4 & $1,172 \mathrm{~d}$ & 46.9 & 100 & $18.1 \mathrm{~b}$ & $0.46 \mathrm{a}$ & $39 \mathrm{~b}$ & Smooth & +++ \\
\hline Smooth Cayenne & $1,618 \mathrm{~b}$ & 64.7 & 138 & $14.8 \mathrm{~cd}$ & $0.41 \mathrm{~b}$ & $36 \mathrm{c}$ & Medium & ++ \\
\hline TNG.17 & $1,341 \mathrm{~cd}$ & 53.6 & 114 & $16.1 \mathrm{c}$ & $0.36 \mathrm{bc}$ & $45 \mathrm{a}$ & Medium & ++ \\
\hline
\end{tabular}

${ }^{\mathrm{z}}$ Index of yield: mean $=$ [Cultivar (selection) fruit weight $/$ C83-5-4 fruit weight $] \times 100$

${ }^{\mathrm{y}} \mathrm{TSS}=$ total soluble solids; TA $=$ titratable acidity.

${ }^{\mathrm{x}}$ Sensory evaluation of pulp fiber and pulp texture was performed by five associates from a trained panel of the Chiayi Agricultural Experiment Station. Samples were tasted and graded based on a scale showing acceptable attributes.

${ }^{\mathrm{w}}$ Means followed by different letters in a column, within the same year, represent significant differences at the $5 \%$ level by Fisher's protected least significant difference test.

$v_{+:}$loose; ++: medium; +++: dense; ++++: very dense.

Table 3. Comparison of horticultural characteristics among TNG.23 (C83-5-4), TNG.17, and Smooth Cayenne ${ }^{z}$ in a $2008-10$ regional trial.

\begin{tabular}{|c|c|c|c|c|c|c|c|}
\hline City/township & Cultivar & Wt per fruit $(\mathrm{g})$ & Yield (t/ha) & Index of yield $(\%)^{y}$ & $\mathrm{TSS}^{\mathrm{x}}\left({ }^{\circ}\right.$ Brix $)$ & $\mathrm{TA}^{\mathrm{x}}(\%)$ & $\overline{\mathrm{TSS} / \mathrm{TA} \text { ratio }}$ \\
\hline \multirow[t]{3}{*}{ Chiayi/Minsyong } & TNG.23 & $1,056 \mathrm{a}^{\mathrm{w}}$ & 42.2 & 95 & $16.7 \mathrm{a}$ & $0.52 \mathrm{a}$ & $32 \mathrm{bc}$ \\
\hline & TNG.17 & $1,117 \mathrm{a}$ & 44.7 & 100 & $15.3 \mathrm{~b}$ & $0.44 \mathrm{~b}$ & $35 \mathrm{ab}$ \\
\hline & Smooth Cayenne & $1,026 \mathrm{a}$ & 41.0 & 92 & $15.0 \mathrm{~b}$ & $0.50 \mathrm{a}$ & $30 \mathrm{c}$ \\
\hline \multirow[t]{3}{*}{ Pingtung/Chaujou } & TNG.23 & $1,025 \mathrm{~b}$ & 41.0 & 86 & $17.9 \mathrm{a}$ & $0.38 \mathrm{~b}$ & $47 \mathrm{a}$ \\
\hline & TNG.17 & $1,191 \mathrm{a}$ & 47.6 & 100 & $16.0 \mathrm{~b}$ & $0.45 \mathrm{a}$ & $36 \mathrm{~b}$ \\
\hline & Smooth Cayenne & $1,137 \mathrm{ab}$ & 45.5 & 95 & $14.9 \mathrm{c}$ & $0.49 \mathrm{a}$ & $31 \mathrm{~b}$ \\
\hline \multirow[t]{3}{*}{ Taitung/Luye } & TNG.23 & $961 \mathrm{~b}$ & 38.4 & 95 & $15.5 \mathrm{a}$ & $0.54 \mathrm{a}$ & $29 \mathrm{a}$ \\
\hline & TNG.17 & $1,015 \mathrm{~b}$ & 40.6 & 100 & $13.9 \mathrm{~b}$ & $0.47 \mathrm{~b}$ & $30 \mathrm{a}$ \\
\hline & Smooth Cayenne & $1,173 \mathrm{a}$ & 46.9 & 116 & $15.1 \mathrm{a}$ & $0.56 \mathrm{a}$ & $27 \mathrm{a}$ \\
\hline \multirow[t]{3}{*}{ Mean } & TNG.23 & 1,014 & 40.6 & 92 & 16.7 & 0.48 & 36 \\
\hline & TNG.17 & 1,108 & 44.3 & 100 & 15.1 & 0.45 & 34 \\
\hline & Smooth Cayenne & 1,112 & 44.4 & 101 & 15.0 & 0.52 & 29 \\
\hline
\end{tabular}

${ }^{\mathrm{z}}$ The seedlings for autumn planting were transplanted in Nov. 2008 and the fruits were harvested from June to July 2010.

${ }^{\mathrm{y}}$ Index of yield: mean $=$ (Cultivar fruit weight $/$ TNG.23 fruit weight $) \times 100$.

${ }^{\mathrm{x}} \mathrm{TSS}=$ total soluble solids; TA $=$ titratable acidity.

${ }^{\mathrm{w}}$ Means followed by different letters in a column, within the same year, represent significant differences at the 5\% level by Fisher's protected least significant difference test.

transplanted to the field in 1995 . Three highly vigorous seedlings with good fruit characteristics, such as no off-flavors or fibrous and tough taste, C81-1-17, C81-2-3, and C81-3-216,

Received for publication 3 June 2019. Accepted for publication 30 July 2019.

This article is part of the Ph.D. dissertation for C.-H. Tang.

C.-H.T. is an Assistant Research Horticulturist.

C.-S.K. is an Associate Research Horticulturist (co-first author).

S.-F.R. is an Associate Professor.

C.-L.L. is an Adjunct Professor.

J.-W.C. is a Senior Research Horticulturist.

I.-Z.C. is a Professor.

J.-W.C. and I.-Z.C. are the corresponding authors. E-mail: chengyo@ntu.edu.tw or jerway@dns.caes.gov.tw. were selected in 2004. The second test was conducted from 1994 to 2006, and seven highly vigorous seedlings with good fruit characteristics were selected, namely C83-1-26, C83-1-387, C83-1-432, C83-1-534, C83-2184, C83-2-750, and C83-5-4 (Fig. 1 illustrates the parental cross). These plants showed a low rate of physiological defects, for example, fewer incidences of stem-end splitting or cracking peel. The main characteristics of seedlings selected in the second progeny test are shown in Table 1 . However, based on the goal of obtaining superior summer fruit, only five plants (C81-1-17, C81-2-3, C81-3-216, C83-1432 , and C83-5-4) were used for the superior line trial.
All highly vigorous seedlings in the progeny tests were 3 years old, with plant heights reaching 40 to $60 \mathrm{~cm}$, before transplantation to the field for evaluation.

Superior line trials. Five superior lines were used, and TNG.17 and Smooth Cayenne were used as the control cultivars from 2006 to 2008. A randomized complete block design (RCBD) was employed with five lines and two cultivars; each line had three replicates, and each replicate had 60 plants. Plants were placed $30 \mathrm{~cm}$ apart, with 50 $\mathrm{cm}$ between rows and $100 \mathrm{~cm}$ between furrows, yielding a plant density of up to 40,000 ha. All seedlings in the superior line trials were side sucker; sucker heights before transplantation were $\approx 60 \mathrm{~cm}$. The 
Table 4. Comparison of horticultural characteristics among TNG.23 (C83-5-4), TNG.17, and Smooth Cayenne in a 2011-13 regional trial.

\begin{tabular}{|c|c|c|c|c|c|c|c|}
\hline City/ township & Cultivar & Wt per fruit $(\mathrm{g})$ & Yield (t/ha) & Index of yield $(\%)^{y}$ & $\operatorname{TSS}^{\mathrm{x}}\left({ }^{\circ} \mathrm{Brix}\right)$ & $\mathrm{TA}^{\mathrm{x}}(\%)$ & TSS/TA ratio \\
\hline \multirow[t]{2}{*}{ Tainan/Shanshang } & TNG.23 & $1,130 \mathrm{c}^{\mathrm{w}}$ & 45.2 & 84 & $17.0 \mathrm{a}$ & $0.41 \mathrm{a}$ & $41 \mathrm{a}$ \\
\hline & Smooth Cayenne & $1,434 \mathrm{a}$ & 57.4 & 106 & $13.2 \mathrm{c}$ & $0.44 \mathrm{a}$ & $32 \mathrm{~b}$ \\
\hline \multirow{2}{*}{ Pingtung/Gaoshu } & TNG.23 & $1,146 \mathrm{~b}$ & 45.8 & 95 & $14.0 \mathrm{a}$ & $0.80 \mathrm{a}$ & $19 \mathrm{a}$ \\
\hline & Smooth Cayenne & $1,406 \mathrm{a}$ & 56.2 & 116 & $10.9 \mathrm{~b}$ & $0.90 \mathrm{a}$ & $12 \mathrm{~b}$ \\
\hline \multirow[t]{2}{*}{ Mean } & TNG.23 & 1,138 & 45.5 & 89 & 15.5 & 0.61 & 30 \\
\hline & TNG.17 & 1,281 & 51.3 & 100 & 13.7 & 0.70 & 23 \\
\hline
\end{tabular}

${ }^{\mathrm{z}}$ The seedlings for autumn planting were transplanted in Nov. 2011 and the fruits were harvested in June and July 2013.

${ }^{\mathrm{y}}$ Index of yield: mean $=($ Cultivar fruit weight $/ \mathrm{TNG} .23$ fruit weight $) \times 100$.

${ }^{\mathrm{x}} \mathrm{TSS}=$ total soluble solids; TA $=$ titratable acidity.

${ }^{w}$ Means followed by different letters in a column, within the same year, represent significant differences at the 5\% level by Fisher's protected least significant difference test.

Table 5. Effect of storage duration on fruit quality of TNG.23 and TNG.17 pineapples.

\begin{tabular}{|c|c|c|c|c|c|c|c|}
\hline Cultivar & Storage (days) & Fruit wt loss (\%) & Abnormal pulp & $\mathrm{IB}^{\mathrm{z}}$ & $\mathrm{TSS}^{\mathrm{y}}\left({ }^{\circ} \mathrm{Brix}\right)$ & $\mathrm{TA}^{\mathrm{y}}(\%)$ & TSS/TA ratio \\
\hline \multirow[t]{3}{*}{ TNG.23 } & $0 \mathrm{~d}$ & $0.0 \mathrm{~d}^{\mathrm{x}}$ & $1.0 \mathrm{c}$ & $1.0 \mathrm{c}$ & $18.2 \mathrm{a}$ & $0.66 \mathrm{ab}$ & 28.1 \\
\hline & $14 \mathrm{~d}$ & $3.8 \mathrm{~b}$ & $1.5 \mathrm{~b}$ & $2.0 \mathrm{~b}$ & $17.4 \mathrm{ab}$ & $0.67 \mathrm{a}$ & 25.8 \\
\hline & $21 \mathrm{~d}$ & $5.3 \mathrm{a}$ & $2.0 \mathrm{~b}$ & $2.5 \mathrm{~b}$ & $16.4 \mathrm{~b}$ & $0.69 \mathrm{a}$ & 23.8 \\
\hline \multirow{3}{*}{ TNG.17 } & $7 \mathrm{~d}$ & $2.5 \mathrm{c}$ & $1.3 \mathrm{c}$ & $1.0 \mathrm{c}$ & $15.2 \mathrm{c}$ & $0.52 \mathrm{~d}$ & 29.2 \\
\hline & $14 \mathrm{~d}$ & $4.1 \mathrm{~b}$ & $2.3 \mathrm{~b}$ & $2.3 \mathrm{~b}$ & $13.8 \mathrm{~d}$ & $0.58 \mathrm{c}$ & 23.8 \\
\hline & $21 \mathrm{~d}$ & $5.5 \mathrm{a}$ & $3.2 \mathrm{a}$ & $4.3 \mathrm{a}$ & $13.4 \mathrm{~d}$ & $0.56 \mathrm{~cd}$ & 23.9 \\
\hline
\end{tabular}

Fruits were stored for 1 to 3 weeks at $15{ }^{\circ} \mathrm{C}$, followed by $4 \mathrm{~d}$ at $25^{\circ} \mathrm{C}$

Fruits were cut longitudinally in halves to identify abnormalities near the flesh around the lower part of the core. For each fruit, abnormalities were scored on a scale from 1 to 5 according to the amount of flesh affected (1, free from abnormalities; $>5 \mathrm{~mm}, 5$ to $10 \mathrm{~mm}, 10$ to $30 \mathrm{~mm},<30 \mathrm{~mm}$ of abnormal flesh).

${ }^{\mathrm{z}} \mathrm{IB}=$ internal browning (symptom of chilling injury), the degree of IB measured by the extent of surface browning of the tissue. They were scored from 1 to 5 , based on the intensity of surface browning of the central tissue around the fruit core. Score $1=$ no chilling injury symptoms, Score $2=$ browning symptoms cover $1 \%$ to $25 \%$ of the surface area, Score $3=$ browning symptoms cover $26 \%$ to $50 \%$ of the surface area, Score $4=$ browning symptoms cover $51 \%$ to $75 \%$ of the surface area, and Score $5=$ browning symptoms cover $76 \%$ to $100 \%$ of the surface area.

${ }^{\mathrm{y}} \mathrm{TSS}=$ total soluble solids; TA $=$ titratable acidity.

${ }^{\mathrm{x}}$ Means of three replicates ( 20 fruits per replicate), followed by different letters in a column, within the same year, were significantly different at the $5 \%$ level by Fisher's protected least significant difference test.

Table 6. Agronomic characteristics of TNG.23 (C83-5-4) and the two control cultivars at Chiayi Agricultural Experiment Station, Taiwan.

\begin{tabular}{|c|c|c|c|c|}
\hline Plant part & Growth characteristics & TNG.23 & TNG.17 & Smooth Cayenne \\
\hline \multirow[t]{4}{*}{ Leaf } & Leaf length & Very short $(43.0 \mathrm{~cm})$ & Medium $(67.2 \mathrm{~cm})$ & Long $(99.8 \mathrm{~cm})$ \\
\hline & Leaf width & Short $(5.1 \mathrm{~cm})$ & Short $(5.0 \mathrm{~cm})$ & Medium $(6.5 \mathrm{~cm})$ \\
\hline & Leaf texture & Medium & Hard & Medium \\
\hline & Leaf color & Green & Green with purple-red & Green with light purple-red \\
\hline Flower & Petal color & Purple & Dark purple & Purple \\
\hline \multirow{4}{*}{ Bud } & Crown length & Short $(11.7 \mathrm{~cm})$ & Short $(13.1 \mathrm{~cm})$ & Long $(24.2 \mathrm{~cm})$ \\
\hline & No. of slips & Medium & Few & Medium \\
\hline & No. of aerial suckers & Few & Few & Few \\
\hline & No. of ground suckers & Medium & Few & Few \\
\hline \multirow[t]{4}{*}{ Fruit } & Weight of fruit & Light $(1.36 \mathrm{~kg})$ & Heavy $(1.48 \mathrm{~kg})$ & Very heavy $(2.26 \mathrm{~kg})$ \\
\hline & Fruit length & Short $(13.8 \mathrm{~cm})$ & Long $(18.8 \mathrm{~cm})$ & Long $(18.4 \mathrm{~cm})$ \\
\hline & Middle of fruit diameter & Medium $(11.8 \mathrm{~cm})$ & Medium $(11.3 \mathrm{~cm})$ & Large $(13.3 \mathrm{~cm})$ \\
\hline & Peel color & Yellow with orange & Yellow with orange-red & Yellow \\
\hline \multirow[t]{7}{*}{ Other } & Pulp texture & Dense & Medium & Rough \\
\hline & Pulp firmness & Soft & Medium & Medium \\
\hline & Total soluble solids & High & High & Medium \\
\hline & Titratable acidity & Medium & Low & Medium \\
\hline & Stem-end splitting & None & High & Low \\
\hline & Cracking peel & None & High & Low \\
\hline & Cut wound surface discoloration & Low & Severe & Medium \\
\hline
\end{tabular}



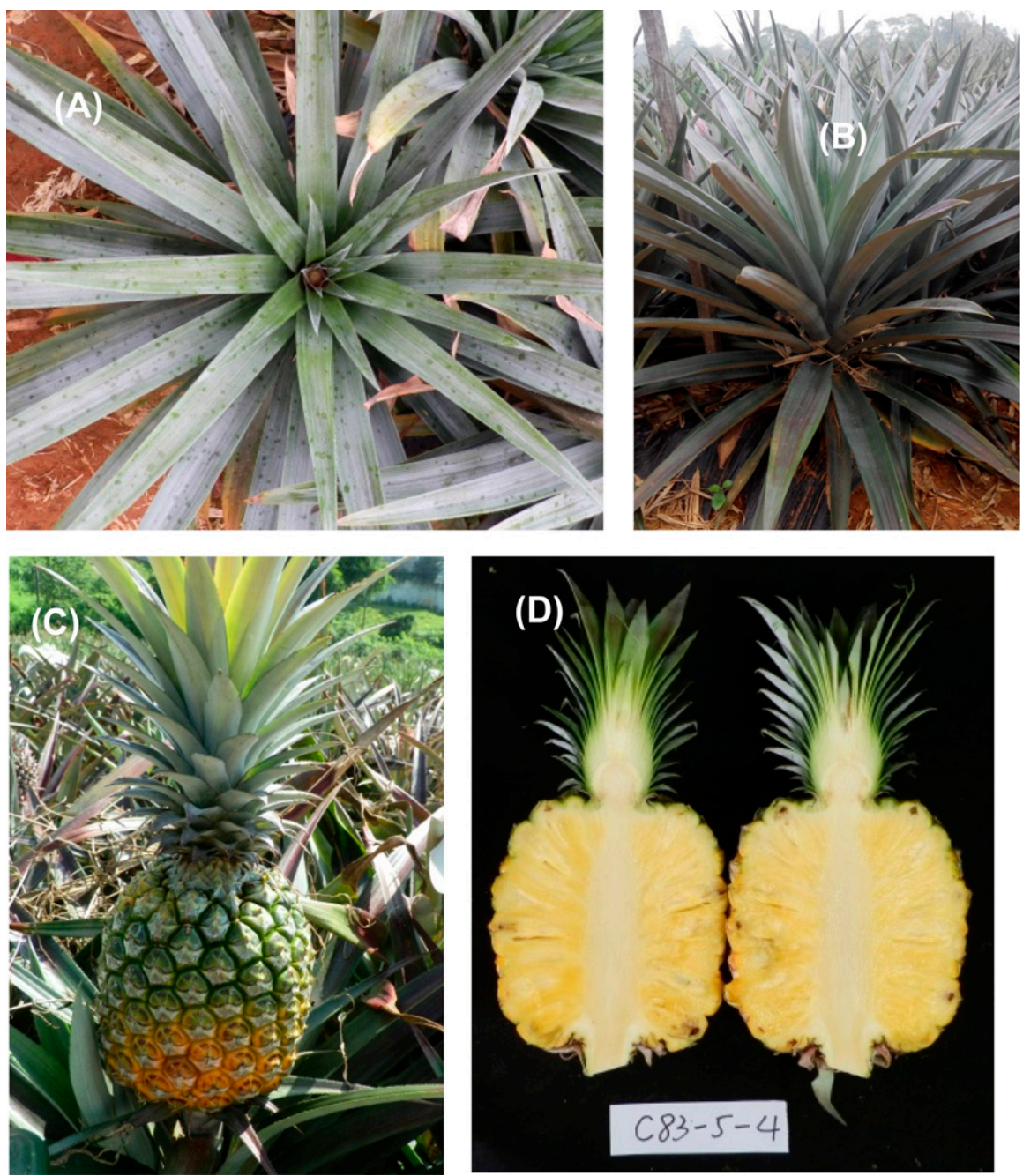

Fig. 2. Individual plant appearance and fruit features of TNG.23 (C83-5-4). (A) Green leaf color; (B) medium growth vigor; (C) short and cylindrical fruit shape and yellow with orange peel color of the mature fruit; (D) light yellow pulp color, and the pulp texture was dense.

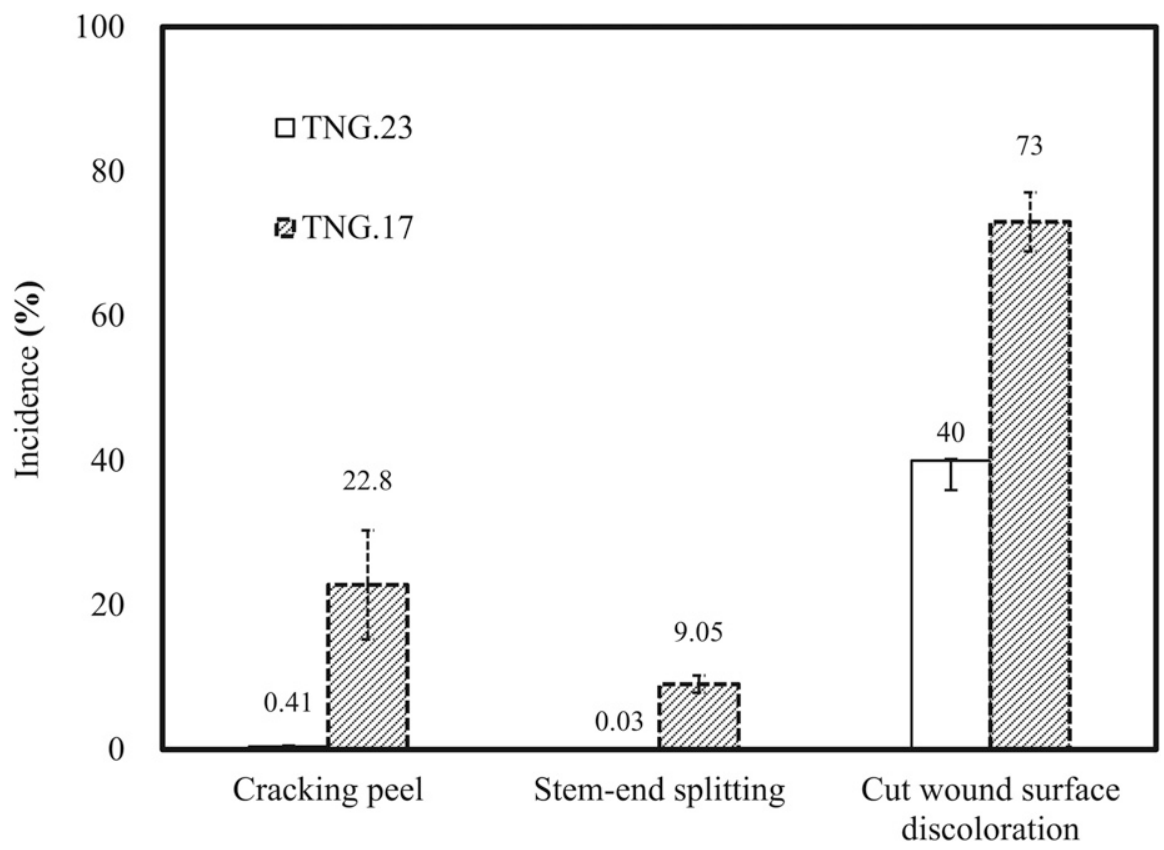

Fig. 3. Physiological disorders of TNG.23 and TNG.17 pineapples. Means of three replicates ( 20 fruits per replicate) with standard error of the mean are shown. Disorder severity, expressed as the percentage of the fruit surface covered by the symptom, was assessed visually and estimated on a scale of $0 \%$ to $100 \%$. average yield and fruit characteristics of the 2 harvest years are shown in Table 2 . The results showed that the summer fruit of C83-5-4 had the finest fiber taste by sensory evaluation, the best pulp texture, high TSS content, medium acid content, proper fruit size, and acceptable yield. Therefore, this line could be considered a good summer pineapple cultivar.

Regional trials. C83-5-4 and two control cultivars, TNG.17 and Smooth Cayenne, were used in a two-step regional trial, which was as follows: 1) The seedling requirements were the same as for the superior line trials. The first step was carried out in 2008 10 in Chiayi, Pingtung, and in Taitung (Taiwan). 2) The second step was in 201113 in Tainan and Pingtung. An RCBD design was used with five replicates; planting density was the same as in the superior line trial. The results of regional trials are shown in Tables 3 and 4. Compared with those of the two control cultivars, C83-5-4 had the smallest fruit size and lowest yield, but the highest fruit quality, especially higher TSS/TA ratio, in most of the trials.

Fruit storability test. To assess fruit storability, C83-5-4 and TNG.17 pineapples were stored at $15{ }^{\circ} \mathrm{C}$ for $21 \mathrm{~d}$ followed by $25^{\circ} \mathrm{C}$ for $4 \mathrm{~d}$. We then assessed weight loss, pulp abnormalities, internal browning, TSS, and TA. The results showed that C83-5-3 demonstrated better storability than TNG 17 (Table 5).

Statistical analysis. The data were subjected to analysis of variance. Significant differences were calculated using Fisher's protected least significant difference test. Differences at $P<0.05$ were considered statistically significant.

Based on the results of the breeding program test, C83-5-4 was certified by the New Plant Certification Committee of the Republic of China and was named 'Tainung No. 23' (TNG.23,, Tainung No. $19 \times$ `Tainung No. 21), also known as mango pineapple.

\section{Performance}

Compared with the six other superior pineapple lines, TNG.23 (line C83-5-4) was shorter $(86.2 \mathrm{~cm})$, being suitable for mechanized harvest using an overhead hoist (an apparatus for harvesting pineapple fruits) handling system. In addition, the plant had fewer leaves (41 leaves), intermediate fruit weight $(1520 \mathrm{~g})$, and fewer fruitlets (130 eyes) (Table 1)

The results of the superior line trials containing TNG.23, four other superior lines, and the control cultivars TNG.17 and Smooth Cayenne are shown in Table 2. TNG.23 had significantly lighter fruit $(1,172 \mathrm{~g})$ than Smooth Cayenne $(1,618 \mathrm{~g})$, and one of the lowest yields $\left(46.9\right.$ t.ha ${ }^{-1}$ ) (Table 2). However, this cultivar had higher TSS content $\left(18.1{ }^{\circ}\right.$ Brix $)$ and TA content $(0.46 \%)$ than those of TNG.17 and Smooth Cayenne in summer, demonstrating that TNG.23 has a 
higher quality taste in summer. Fruit weight and fruit quality were compared among TNG.23, TNG17, and Smooth Cayenne in the regional trial conducted in 2008-10 (Table 3) and 2011-13 (Table 4). There were significant differences in weight per fruit among TNG.23, TNG.17, and Smooth Cayenne at two experimental sites in 2011-13, while there were no significant differences at the Chiayi experimental site in 2008-10. The average TSS content of TNG.23 among the five experimental sites ranged from 14.0 to $17.9{ }^{\circ} \mathrm{Brix}$ (15.5 to $16.7^{\circ} \mathrm{Brix}$ were the mean values of the two trials), which was significantly higher than the TSS in both TNG.17 and Smooth Cayenne. TNG.23 had less abnormal pulp and internal browning than TNG.17 after 14 and $21 \mathrm{~d}$ of storage at $15{ }^{\circ} \mathrm{C}$ (Table 5; at the $5 \%$ level by Fisher's protected least significant difference test), demonstrating good storability at this temperature.

TNG.23 is characterized by a very short plant height and short leaf length, low fruit weight (Table 1), short cylindrical shape, medium fruitlet size, dense pulp texture (Table 6; Fig. 2), and reduced incidence of fruit physiological disorders (Fig. 3). The storability of TNG.23 is as good as TNG.17. The fruit quality remains good in summer, unlike the current widely used cultivars in Taiwan; therefore TNG.23 fulfills the objective of this pineapple breeding project.

\section{Availability}

This cultivar can be obtained through authorization of the variety. The authoriza- tion requests should be sent to the Taiwan Agricultural Research Institute.

\section{Literature Cited}

Chang, C.C., H.T. Hsu, and Y.H. Cheng. 1999. A new pineapple variety - 'Tainung No.17'. HARVEST Farm Magazine. 49:21-23. (In Chinese).

Republic of China (Taiwan) Statistics Bureau. 2018. Statistical yearbook of the Republic of China 2017. Republic of China (Taiwan) Stat. Bureau, No. 2, Taipei City, Taiwan, R.O.C. $<$ https://eng.stat.gov.tw/lp.asp?CtNode $=2815 \&$ CtUnit $=1072 \&$ BaseDSD $=36 \& m p=5>$.

Tsai, H.W., C.H. Tang, and C.S. Kuan. 2015. Effect of planting time and flower forcing on fruit development and quality in pineapple 'Tainung No.17'. Crop, Environment \& Bioinformatics 12:155-165.

$\mathrm{Wu}, \mathrm{Y} . Z .2012$. Effects of bagging and nitrogen on peel color and translucency in pineapple (Ananas comosus) fruit. Taiwan Univ.,Taipei, MS thesis p. 77. (In Chinese) 